\title{
Congress wrestles with electronic highway bill
}

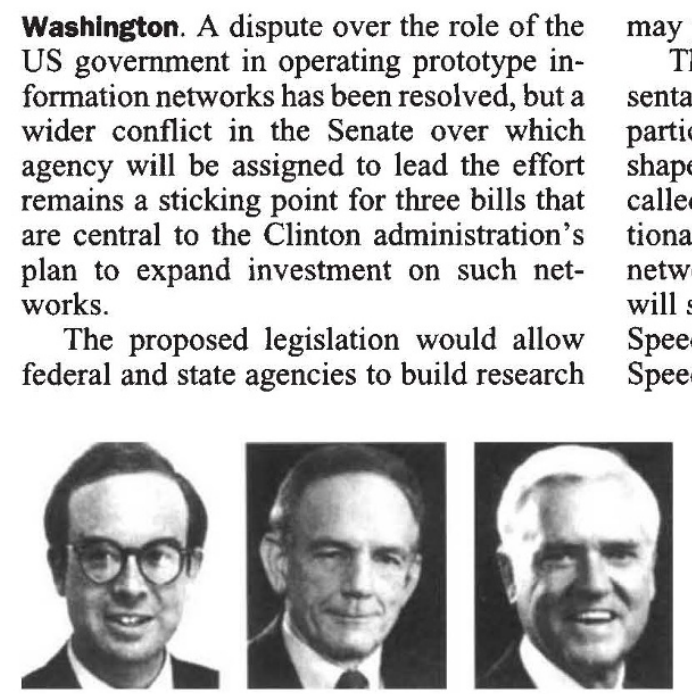

From left, Boucher, Johnston and Hollings.

'testbeds' of high-speed information networks and develop computer software to help schools, libraries, universities and government departments use the networks.

Strong lobbying by the telecommunications industry has resulted in a provision that would, 18 months after the bill is enacted, prohibit testbeds from being used for any services that could be provided commercially. This ban meets industry concerns that successful, state-subsidized testbed networks - such as the National Science Foundation (NSF)'s existing NSFNET undermine the viability of commercial alternatives as well as satisfying those who hold that the government should not operate such services. But academic scientists are worried that a blanket ban would disrupt their work on the networks, and a compromise is being drawn up to meet their concerns by extending the transition and giving agencies greater discretion on its execution.

The provision is designed to ensure that future, multi-agency networks developed under the auspices of the National Research and Education Network (NREN) are swiftly transferred to the private sector in the same way that NSF is now planning to transfer users of NSFNET (see Nature 362, 582; 1993). The NSF has said it will provide sufficient funds to enable scientists to continue their work, but the legislation will not guarantee access.

The proposals, which would cost less than $\$ 100$ million in their first year, are already part of the president's budget proposal for fiscal year 1994, which starts on 1 October this year. In subsequent years, however, the annual cost would rise to $\$ 400$ million, and budgetary constraints may prevent full implementation.

Three bills - one in the House of Representatives and two in the Senate - are of particular importance in determining the shape of government support for the socalled information superhighway - a national, high-capacity telecommunications network that the administration believes will strengthen the US economy. The High Speed Performance Computing and High Speed Networking Act, sponsored by Rick Boucher (Democrat, Virginia), chairman of the science subcommittee of the House Science, Space and Technology Committee, is the only one of the three devoted specifically to information technology.

The Boucher bill amends the 1991 High Performance Computing Act to require the Office of Science and Technology Policy (OSTP) to plan and run a five-year programme for networking research. The National Science Foundation (NSF) would take a leading role, spending around half of the $\$ 1.5$ billion needed to build network testbeds, subsidize schools and universities to use networks and develop applications.

OSTP director John Gibbons testified two weeks ago that Boucher's bill was "important and forward-looking legislation" but that it contains three flaws. Gibbons says there is no need for a fifth OSTP associate director to run the programme but that the bill should acknowledge the role of the education, energy and defence departments. In addition, he says that restrictive language on when 'testbed' networks must be transferred to the private sector "would complicate an already difficult task".

Boucher concedes that 18 months is an "arbitrary" length of time but says that any compromise must uphold the principle that publicly funded networks should not do commercial work. The issue of a fifth associate directorship may be resolved by assigning responsibility for the information network to someone of lower rank.

After that, the going gets rougher. Two bills in the Senate sponsored by powerful committee chairmen - the Department of Energy National Competitiveness Technology Partnership Act by J. Bennett Johnston (Democrat, Louisiana) and the National Competitiveness Act by Ernest Hollings (Democrat, South Carolina) - each contain sections dealing with the information network. But Democratic leaders would like to merge the two bills. Johnston's gives the Department of Energy a leading role, while Hollings's favours the Commerce Department, so these differences would need to be reconciled before a vote is taken.
Holling's bill is closely aligned to what the administration wants to do, and its provisions on an information highway contain objectives similar to those of Boucher's bill, including rules for the transfer of testbeds to the private sector. It also incorporates a proposal by Senator Bob Kerrey (Democrat, Nebraska) to develop more efficient ways to digitize library books. Johnston's bill specifies a role for Department of Energy laboratories in various aspects of network development and application as part of a \$300-million programme over three years.

Colin Macilwain

\section{Germany names eastern engineer to research post}

Munich. Germany today swears in its third research minister this year after Matthias Wissmann was promoted to the transport ministry after only 106 days in office. The appointment of east German Paul Krüger,
IMAGE UNAVAILABLEsurprise, even to UNAVAILABLE him: "I was shocked FOR [by the offer]", he COPYRIGHT says, "but thinking it REASONS over I very quickly accepted".

A mechanical

\section{Paul Krüger} engineer by profession, Krüger has had a short but very successful political career. He joined the Christian Democrat party (CDU) after the fall of the Berlin Wall in 1989 and became a member of the East German parliament after the first democratic elections in March 1990 and subsequently a member of the new German parliament following reunification. Since then he has been a member of the parliamentary committee on science and technology. $\mathrm{He}$ joined the industry and economics committee last year, where he has been active in campaigning for greater support for industry in eastern Germany.

Germany's research ministry has had a turbulent year. In January, a surprise government reshuffle removed Heinz Riesenhuber, Germany's longest serving research minister, after 10 years in the job. He was succeeded by Wissmann, a lawyer whose youth and constituency were more in line with Chancellor Helmut Kohl's expectations of a geographically balanced cabinet (see Nature 361, 286; 1993). But Wissmann became Germany's shortest serving research minister when he was offered the transport ministry last week after Günther Krause, an east German, was forced to resign after a series of corruption scandals. Krüger's appointment preserves that geographic balance.

Alison Abbott 